\title{
5 Corporate Governance and Business Growth
}

\author{
Evidence From China
}

\author{
Jia Liu, Dimitrios Stafylas, Junjie Wu \\ and Christopher Muganhu
}

\section{Introduction}

Since 1978, China has progressively embraced market principles, establishing an increasingly free market economy and financial system. Stateowned enterprises (SOEs) have gradually become privatised corporations, regulated by laws and codes of practice for the control of markets and investor protection, creating strong foundations for the development of a market economy. These advances have helped China to become the second greatest economy in the world (World Bank in China, 2017).

Corporate governance in China has undergone a revolution, driven by the economic reforms of 1978. Between 1945 and 1978, the economy was dominated by state owned and controlled enterprises. However, the policies adopted from 1978 encouraged entrepreneurship. Two stock exchanges now channel funds to the corporate sector and security policies and governing bodies have been established at central and local levels. Ownership reform has reduced state control of commerce and industry from 100 percent in 1978 to 51 percent in 2009 and to 30 percent in 2015 , increasing investors' confidence in markets, based on the CSMAR database. This has also been reinforced by the Code of Corporate Governance of 2002, which strengthened the Chinese corporate sector.

However, despite these achievements, political connections strongly influence institutional change, with the state acting as both regulator and actor in commerce. A dual-share ownership structure maintains state dominance, and listed firms have ineffectual boards of directors that undermine attempts to protect investors.

In this chapter, we evaluate Chinese corporate governance and its interactions with the internal and external institutional environments. We perform an empirical analysis of mergers and acquisitions, presenting evidence to show how corporate governance has influenced company growth. Our findings will be of value to China and other economies that are now or will in future pursue similar trajectories.

In Section 2, we review corporate governance reforms, issues and challenges. Section 3 presents an empirical analysis of corporate governance 


\section{Jia Liu et al.}

and value creation by investigating mergers and acquisitions in China. Section 4 concludes with policy recommendations.

\section{Corporate Governance Mechanism in China}

\section{Evolution of Corporate Governance Mechanism in China}

In China, corporate governance was considered insignificant until the mid-1990s. The first attempt at reform was the PRC Company Law of 1994, which established the foundations of what was to follow. In 2002, the China Securities Regulation Commission (CSRC) and the State Economic and Trade Commission published the Code of Corporate Governance for Listed Firms in China, based on the principles of the Organisation for Economic Cooperation and Development (Principles of Corporate Governance, 1999). The primary objective was to regulate shareholders' meetings, directors' roles and the constitution of boards, the role of supervisory boards, performance measurement and incentives, disciplinary systems and investor protection. This helped to increase investors' confidence and to stabilise Chinese companies.

Another significant reform was of the share-split structure of publicly listed companies, whose objective was to reduce state domination by transforming non-tradable state-owned shares into tradable 'A' shares, for trading by foreign and domestic private investors. This will reform corporate control and enhance the monitoring and accountability of listed companies (Liu and Li, 2014; Liu et al., 2018).

Nevertheless, the institutional framework remains weak and regulations are difficult to apply. Canada's Centre for International Governance Innovation placed China first out of ten Asian countries in adopting OECD principles, but ninth in applying these in practice (Liang \& Useem, 2009). Considerable improvements are thus required to eliminate such deficiencies.

\section{Issues of Internal Corporate Governance in China}

Despite state regulation, China's economic system has unique problems, whose resolution is essential for the creation of effective systems of internal and external governance.

\section{State Ownership and Ownership Concentration}

Directly or indirectly, state agencies retain control of two-thirds of listed firms' shares, and state-controlled shares are non-tradable. Even though centralised control has been reduced by the split-share structure reform of 2005, enterprise in China is still dominated by the state. 
Most firms have a single, controlling stockholder, with a direct or indirect relationship with government or government agencies. By the end of 2000, the median of the largest, individual shareholder's holding was 42.6 percent, while the second largest held only 5 percent of shares and the third 1.9 percent, and there were few private investors. Ownership by managers and employees is limited in listed firms, as is ownership by foreign noninstitutional investors (Chen et al., 2009). According to our data (Table 5.2), the state controls 30 percent of listed firms' share capital, institutional investors hold only 17 percent and management own less than 2 percent.

Given the state's dominance, ownership structure often takes the form of 'pyramid holdings', with shares being held by the state or its agencies (Kakabadse et al., 2010). The management structure in state enterprises is hierarchical, with power exerted by the government through the China State-owned Assets Management Bureaucracy and the Local State-owned Assets Management Bureau (LSAMB). The latter appoints managers to SOEs at local government level, but it does not have enough resources to monitor such companies. The managers of SOEs themselves lack serious motivation to maintain and add value to the state assets they control 'because they do not hold the absolute ownership of these assets' (Wei \& Geng, 2008). Consequently, the LSAMB cannot affect the real control needed for motivating directors and managers.

\section{Political Connections}

Most listed firms were originally owned and managed by the state and listed with the state as majority shareholder. Such firms have two-thirds of directors who are either directly or indirectly state appointed. Previous studies of such firms in developing and emerging countries demonstrate that they enjoy extensive advantages and gain significantly from their political connections (e.g. La Porta et al., 1999; La Porta et al., 2000; Khwaja \& Mian, 2005; Faccio, 2006; Bunkanwanicha \& Wiwattanakantang, 2009). They also benefit from lower tax rates, have a greater market share than competitors without political connections (Khwaja \& Mian, 2005), and are more likely to receive financial support in financial distress (Faccio et al., 2006). They can also lobby government in pursuit of favourable policies and maintenance of the status quo (Liu \& Pang, 2009; Guo et al., 2018).

Research evidence shows that political connections exert a positive, short-term effect on a firm's performance, especially when they are with senior members of government, although in the long-term political connections have a negative effect on firm performance (Faccio, 2006). Fan et al. (2007) show that a CEO's political ties result in more government officials being appointed to the board than professional managers. This is attributed to the distinctive political culture that prevails in the Chinese economic system. 


\section{Jia Liu et al.}

\section{Weak Internal Corporate Governance}

The Chinese system of corporate governance incorporates both AngloSaxon and German principles. The Code requires a two-tier board, comprising a supervisory board and the board of directors. The supervisory board monitors the executive board and advises senior executives, but it takes no direct part in running a company. Chinese supervisory boards are effectively powerless, having no authority to appoint or dismiss directors, unlike supervisory boards in Germany. Some studies show that supervisory boards in China exert scant influence, merely endorsing management's decisions (Ding et al., 2009). Clearly supervisory boards play only a symbolic role and are merely decorative (Liu et al., 2014).

In China, corporate governance is effectively directed by a single board of directors, strongly influenced by the largest shareholders. Independent directors exert only a token influence because of the active intervention of controlling shareholders (Lin et al., 2009). To protect shareholders' interests, the CSRC promulgated the Guideline on Establishment of Independent Director System in Listed Companies in 2007, requiring at least one-third of a board's seats to be held by independent directors. However, almost all companies comply with this regulation only for the sake of appearance. In fact, most so-called 'independent' directors are appointed by controlling shareholders, representing the owners rather than minority shareholders.

\section{External Corporate Governance Environment}

The strength of the corporate governance mechanism is determined by its internal structure and its external environment. However, the latter holds the greater power of enforcement, particularly for the protection of ownership rights, the enforcement of the rule of law, the regulation of market competition, the imposition of an information disclosure mechanism, the creation of independent audit systems and the market for corporate control. Hence, external monitoring systems perform a vital role in determining conduct and governance.

Effective corporate governance is founded upon the strength and probity of the environment in which companies operate. To improve stock market efficiency and safeguard shareholders' interests, the CSRC established a corporate disclosure regulatory framework and a series of regulations requiring listed firms to make disclosures that are truthful, accurate, complete and timely, enabling investors to make informed decisions. Further, the two stock exchanges have developed systems of corporate governance, issuing a series of rules and regulations to protect investors' interests and increase transparency of disclosure. However, legal defects still abound, and insider trading and earnings management are rampant among Chinese listed firms. 
Certified accountants tend not to issue modified audit reports (Ke et al., 2015) and the falsification of financial reports remains a significant problem (Firth et al., 2011).

With dominant interests rampant, systems of governance will inevitably be compromised. In China, continual government intervention undermines laws meant to protect investors. Corporate funds raised for legitimate purposes are frequently appropriated by dominant shareholders for improper uses without shareholders' consent. Both stock exchanges have sought to control such malfeasances by regulating information disclosure, developing robust systems to promote transparency and publicising breaches. Nevertheless, public shareholders are yet to receive effective protection. Dominant shareholders seek to maximise social welfare instead of corporate value to conform to political demands. Managers have little incentive to maximise corporate value as they are more strongly motivated to implement the decisions of the controlling shareholders who appointed them (Liu et al., 2016). In particular, state intervention and hierarchical ownership structures protect managers from the consequences of poor decision-making as reflected by capital markets. The weak institutional environment makes it difficult for rules to be enforced, which undermines the system of corporate control.

In summary, corporate governance in China is significantly shaped by high ownership concentration, characterised by state dominance and political affiliations. State control degrades a company's corporate governance system as well as the rights of minority shareholders. Management and board decisions favour the interests of the controlling shareholders who appointed them. This has inevitably led to agency problems in the form of tunnelling of resources and management's pursuit of political interests to the detriment of minority shareholders. Internal governance is further weakened by ineffective enforcement of regulations and laws and by an inefficient financial market. These factors have exacerbated conflicts of interest between dominant and minor shareholders, leaving the latter unprotected.

Our inquiry is grounded in this unique economic environment, and the results of our empirical analysis will explain how the corporate governance mechanism shapes company growth in China. To this end, we shall investigate the case of mergers and acquisitions (M\&A) undertaken by Chinese companies, which have been largely encouraged by the restructuring of state ownership following the share-split structural reform that began in 2005. Acquisitions have focused on restructuring state-owned assets, with local governments reallocating assets from the target company to the acquirer. They are primarily motivated by social, non-economic concerns, ignoring economic considerations, as large state holdings protect them. The state sees M\&A activities as a key driver of the reform process, using this mechanism to rescue failing SEOs by combining them with healthy firms. Against this socio-economic background, 


\section{Jia Liu et al.}

the impact of mergers and acquisitions on corporate governance and control will be significant. It is therefore important to investigate a strong example of such a case.

\section{The Role of Corporate Governance in Business Growth: Evidence From Mergers and Acquisitions in China}

\section{Theoretical Background and Research Questions}

Managers claim to maximise corporate value by their M\&A activity (Berkovitch \& Narayanan, 1993). Given efficient markets and rational managers, synergistic M\&As should create value for shareholders (Gaughan, 2010; Petitt \& Ferris, 2013). Gains are achieved by improved operational efficiency, greater market power and the more efficient employment of limited capital. However, if markets are inefficient and managers irrational, M\&As destroy value due to managerial hubris (Roll, 1986; Wang \& Hickson, 2009; Weitzel \& McCarthy, 2011) or lead to private utility maximisation (Campbell et al., 2011). Managers of acquiring firms, motivated by personal interests, may fail to recognise potential economic gains from a merger or a takeover; or they may miscalculate the target firm's value due to cognitive limitations, paying more than it is worth.

Acquiring firms in China are mainly large and powerful, with the state as the majority shareholder. Target firms are mainly privately owned, financially distressed and small, and are usually cowed into accepting lower bidder valuations of their firms. Earlier studies suggest that M\&As in China create no value for the shareholders of acquiring firms because they fail to undertake due diligence. Moreover, the State exerts pressure through local governments, compelling listed companies to acquire bankrupt firms (Zhang, 2003). Government involvement in the M\&A process, as both player and regulator, has interfered with the functioning of internal governance systems, undermining board effectiveness and management accountability. This is certain to influence corporate investment decisions and hence the corporate value to be gained through a merger and acquisition.

The foregoing discussions lead to our research questions: (1) Do corporate governance mechanisms facilitate business growth at the firm level?; (2) Can an integral system of corporate governance enhance corporate value?; (3) What influences can acquirers' characteristics, deal characteristics and industry-level features, which are associated with M\&A activities, have on corporate growth?

\section{Data and Sampling}

Our study examines M\&A deals that were successfully completed between 2002 and 2015 by Chinese listed firms. We employ the Mergers and 
Acquisitions Database, China's Stock Market Database, the Corporate Governance Database and the Accounting Research Database supplied by CSMAR. We include the firms and M\&A deals that satisfy the following criteria: 1) the acquirer is a firm with Class 'A' shares traded on the Shanghai or Shenzhen Stock Exchanges; 2) the target firm can be a publicly listed firm or a private firm; and 3) M\&As are undertaken by companies that operate in the financial sector.

Our final sample comprises 2, 639 M\&A transactions involving 1, 127 acquiring firms.

\section{Empirical Modelling}

To perform empirical analyses, we adopt cross-sectional ordinary least squares (OLS) regression analysis with clusters. There are cases where a particular firm was involved in more than one acquisition over the course of the fourteen-year study period. The business growth of these firms may not be independent, which can lead to residuals that are not independent between the firms. To address this potential problem, we use standard errors adjusted for heteroscedasticity, as suggested by White (1980). The cross-sectional regression model is specified below.

$$
\begin{aligned}
& \text { Firm growth }_{i, t}=\alpha_{0}+\sum\left(\text { corporate governance }_{i, t}\right) \beta_{1}+ \\
& \left.\sum \text { controlvariables }_{i, t}\right) \beta_{2}+\varepsilon_{i, t}
\end{aligned}
$$

where Firm growth ${ }_{i, t}$ is measured by market-book ratio. We employ a range of variables, which are structured so as to examine systematically the possible outcomes as a result of mergers and acquisitions. Specifically, we examine if, and how, the possible outcomes of merger and acquisition activities are themselves shaped by the strength of corporate governance structures. Our first set of variables focuses on the corporate governance of acquiring firms, which comprised two groups of variables: (1) ownership: state ownership, institutional ownership and executive ownership; (2) corporate governance: director independence, CEO/chairman duality and board size; and (3) corporate governance index. The vector of control variables includes three sets of variables: (1) acquirers' characteristics: stock price run-up, sales growth, return on assets, leverage, firm size, geographical focus, related party transactions; (2) deal characteristics: value of the transaction, method of payment, listing status of the target firm (private target), diversifying (focusing) acquisition and previous M\&A experience; (3) product market competition variables: competitive industry and unique industry. In addition, year and industry dummies are also included as control variables to account for year and industry effects in the estimations. Variable definitions are presented in Table 5.1. 


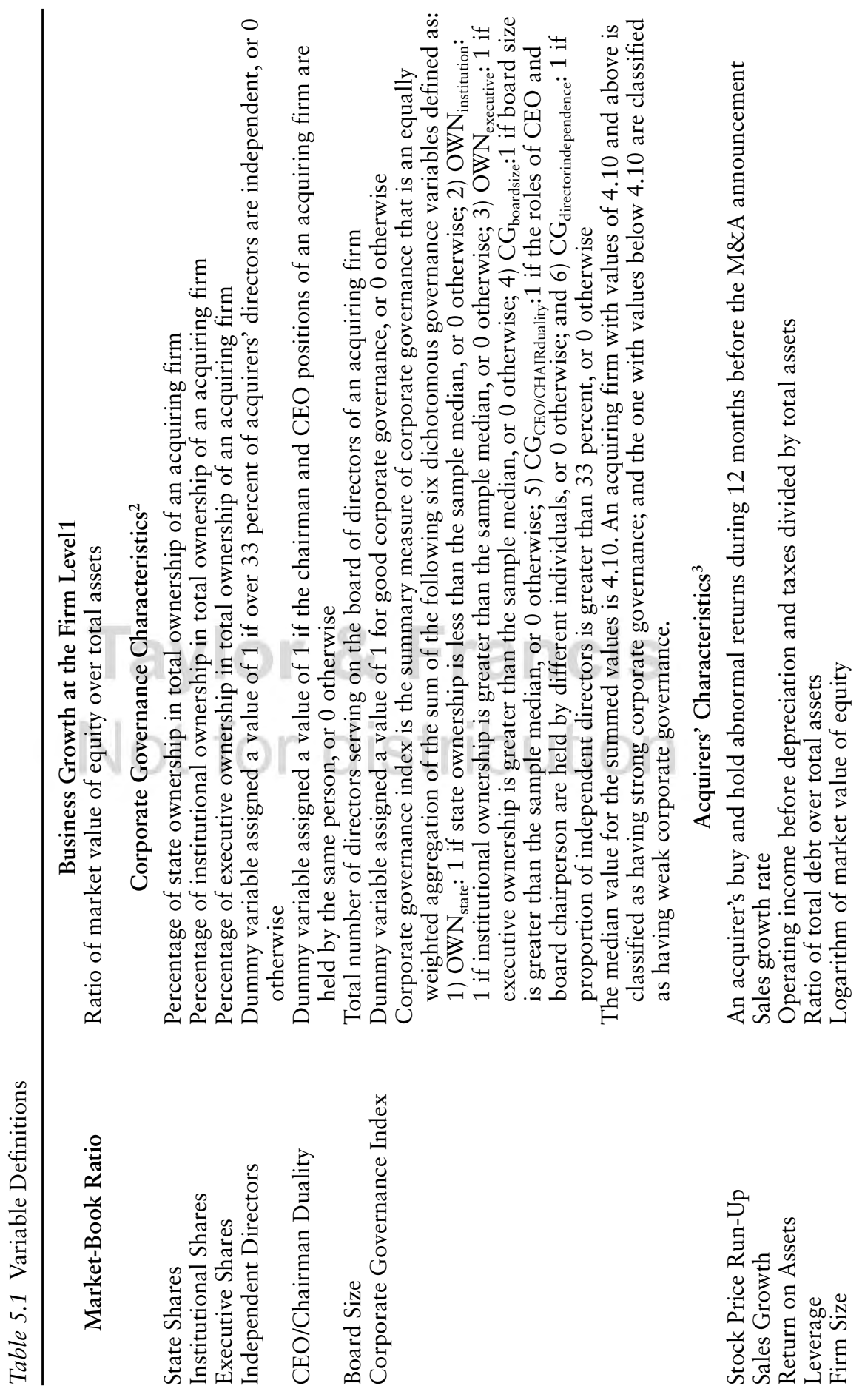




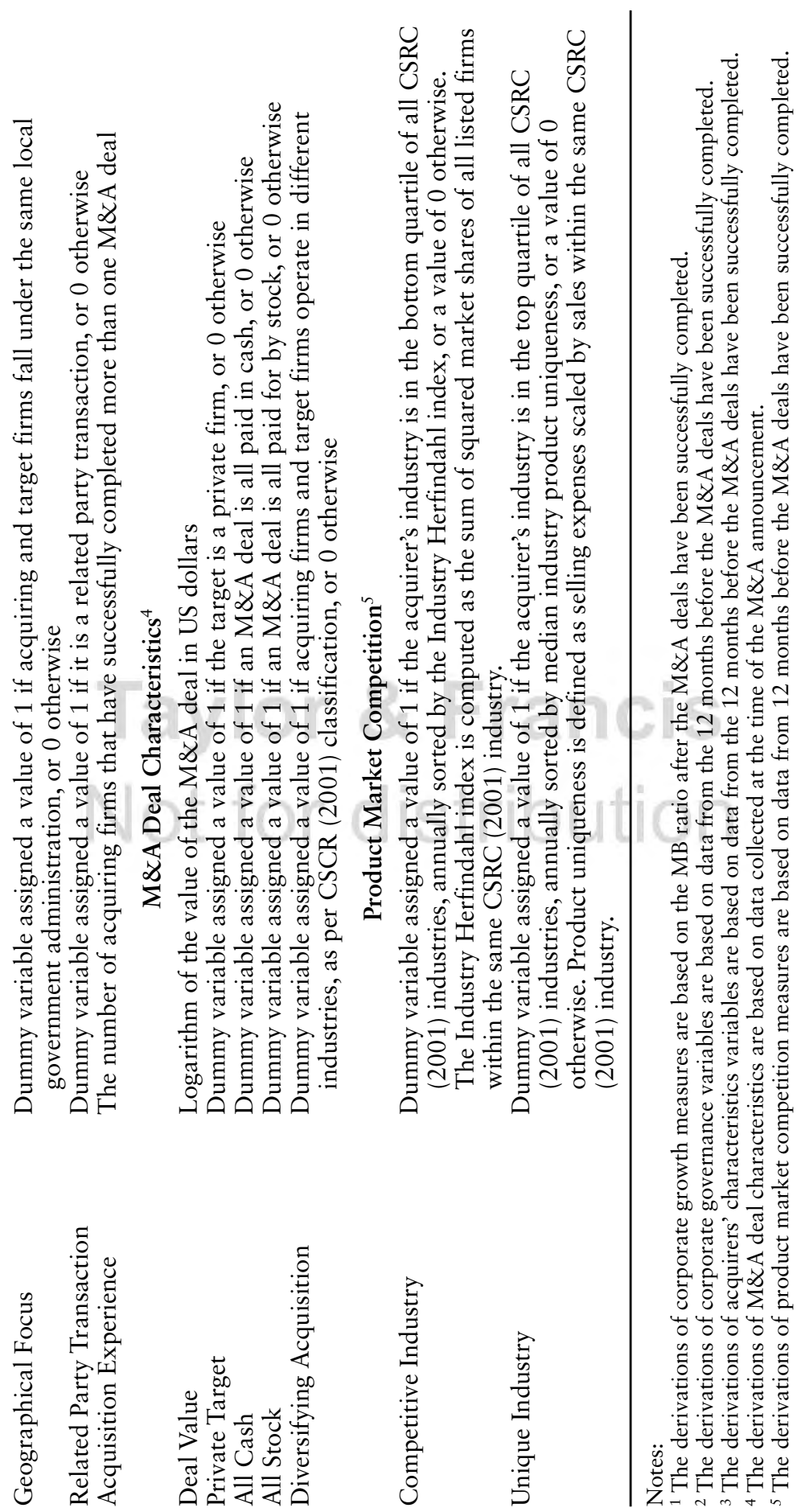




\section{Jia Liu et al.}

\section{Empirical Results and Discussions}

\section{Descriptive Statistics}

Table 5.2 presents distribution of M\&A deals by the year of announcement. Generally, M\&A activities increased in both the number of deals and the value of the transactions over the sample period. The M\&A deals increased from 91 in 2002 to 302 in 2015. The mean value of M\&A deals increased from US \$16.03 million in 2002 to US \$141.89 million in 2015. The mean acquirers' market value of equity increased from US $\$ 551.36$ in 2002 to US \$1302.27 in 2015, suggesting that large firms are engaging more in M\&A activities, especially from 2008. Overall, these statistics demonstrate that during the reference period, Chinese companies became increasingly active in M\&A undertakings, in particular after 2005 when the split-share structure reform was introduced.

Table 5.3 presents the summary statistics of the variables for the estimations. The average $\mathrm{MB}$ ratio is 2.34 , which implies that acquiring firms may be overvalued. The statistics shows some salient features of corporate governance mechanism in China. On average, state ownership accounts for 29.19 percent; institutional ownership accounts for 17.42 percent, while executive ownership is almost negligible at 0.61 percent. There has been a quite significant reduction in state ownership as shown by our sample, compared to 84.0 percent in 2001 and 46.6 percent in 2005

Table 5.2 Distribution of M\&A Deals by the Calendar Year

\begin{tabular}{llll}
\hline & $\begin{array}{l}\text { Number of } \\
\text { M\&A Deals }\end{array}$ & $\begin{array}{l}\text { MoA Deal } \\
\text { Value } \\
\text { (USD Millions, } \\
\text { Mean) }\end{array}$ & $\begin{array}{l}\text { Acquirers' } \\
\text { Market Value of } \\
\text { Equity } \\
\text { (USD Millions, } \\
\text { Mean) }\end{array}$ \\
\hline 2002 & & & 551.356 \\
2003 & 121 & 16.029 & 652.867 \\
2004 & 130 & 24.816 & 782.404 \\
2005 & 107 & 16.667 & 348.468 \\
2006 & 106 & 14.358 & 684.367 \\
2007 & 186 & 24.167 & 618.245 \\
2008 & 182 & 39.294 & 1970.531 \\
2009 & 201 & 74.170 & 2377.238 \\
2010 & 206 & 63.501 & 1978.357 \\
2011 & 207 & 59.228 & 1687.248 \\
2012 & 256 & 38.528 & 1488.252 \\
2013 & 265 & 42.014 & 1569.883 \\
2014 & 279 & 82.109 & 1401.065 \\
2015 & 302 & 87.536 & 1302.272 \\
\hline
\end{tabular}

Note: The sample consists of 2, 639 successfully completed mergers and acquisitions undertaken by Chinese firms between 2002 and 2015. 
Table 5.3 Summary Statistics

\begin{tabular}{|c|c|c|c|c|}
\hline & Mean & $\begin{array}{l}\text { Standard } \\
\text { Deviation }\end{array}$ & Minimum & Maximum \\
\hline $\begin{array}{l}\text { Dependent Variable } \\
\text { MB Ratio }\end{array}$ & 2.338 & 0.259 & 0.000 & 0.863 \\
\hline $\begin{array}{l}\text { Ownership Structure } \\
\text { State Shares } \\
\text { Institutional Shares } \\
\text { Executive Shares } \\
\text { Board Structure } \\
\text { Independent Directors } \\
\text { CEO/Chairman Duality } \\
\text { Board Size }\end{array}$ & $\begin{array}{c}29.191 \\
17.421 \\
0.610 \\
\\
33.836 \\
30.82 \\
9.478\end{array}$ & $\begin{array}{r}25.979 \\
22.732 \\
3.685\end{array}$ & $\begin{array}{l}0.000 \\
1.000 \\
5.000\end{array}$ & $\begin{array}{r}66.667 \\
2.000 \\
19.000\end{array}$ \\
\hline $\begin{array}{l}\text { Acquirers' Characteristics } \\
\text { Stock Price Run-Up } \\
\text { Sales Growth } \\
\text { Return on Assets } \\
\text { Leverage } \\
\text { Firm Size } \\
\text { Geographical Focus } \\
\text { Related Party Transactions }\end{array}$ & $\begin{array}{r}-24.956 \\
26.434 \\
5.265 \\
0.309 \\
1.335 \\
0.735 \\
0.605\end{array}$ & $\begin{array}{r}95.011 \\
48.809 \\
6.086 \\
0.196 \\
7.208 \\
0.442 \\
0.489\end{array}$ & $\begin{array}{r}-462.923 \\
-79.225 \\
-32.214 \\
0.000 \\
0.026 \\
0.000 \\
0.000\end{array}$ & $\begin{array}{r}463.222 \\
610.681 \\
49.697 \\
0.932 \\
241.169 \\
1.000 \\
1.000\end{array}$ \\
\hline $\begin{array}{l}\text { Deal Characteristics } \\
\text { Deal Value (USD Millions) } \\
\text { Private Target } \\
\text { All Cash } \\
\text { All Stock } \\
\text { Diversifying Acquisition } \\
\text { Acquisition Experience }\end{array}$ & $\begin{array}{r}42.948 \\
0.945 \\
0.918 \\
0.036 \\
0.902 \\
0.734\end{array}$ & $\begin{array}{r}200.767 \\
0.157 \\
0.244 \\
0.183 \\
0.298 \\
0.444\end{array}$ & $\begin{array}{l}1.001 \\
0.000 \\
0.000 \\
0.000 \\
0.000 \\
0.000\end{array}$ & $\begin{array}{r}4,801.538 \\
1.000 \\
1.000 \\
1.000 \\
1.000 \\
1.000\end{array}$ \\
\hline $\begin{array}{l}\text { Product Market Competition } \\
\text { Competitive Industry } \\
\text { Unique Industry }\end{array}$ & $\begin{array}{l}0.322 \\
0.264\end{array}$ & $\begin{array}{l}0.467 \\
0.441\end{array}$ & $\begin{array}{l}0.000 \\
0.000\end{array}$ & $\begin{array}{l}1.000 \\
1.000\end{array}$ \\
\hline Observations & 2,017 & 2,017 & 2,017 & 2,017 \\
\hline
\end{tabular}

Note: The sample consists of 2, 639 successfully completed mergers and acquisitions undertaken by Chinese firms between 2002 and 2015. The variable definitions are in Table 5.1.

reported by Liu and Sun (2005) and Chi et al. (2011), respectively. The reduction is largely ascribed to the share-split structure reform introduced in 2005. Despite the reduction, the ownership structure of Chinese firms has maintained the government's power to control their operations.

In respect of the board structure and composition, independent directors account for 33.84 percent of the board, which is in compliance with the CSRC's requirement that independent directors should constitute at least one-third of a board. CEOs holding dual positions account for 30.82 percent of our sample. The total number of board directors is in a range of 5 to 19 , with an average board size being 9.48 . 


\section{Jia Liu et al.}

With regards to acquirers' characteristics, RUNUP is -24.96 percent on average, which suggests that the market lacks confidence in acquiring firms in the period of leading up to the M\&A announcement. The average sale growth is at $26.43 \%$ with a considerable variation among acquiring firms. Acquirers have an average return on assets of 5.27 , with values falling between a minimum of -32.21 and a maximum of 49.70 . On average, at a level of 0.14 , leverage for our sample is lower than the values of 0.50 and 0.24 reported by Li, Feng \& Cao (2011) and Pukthuanthong-Le and Visaltanachoti (2009), respectively. The size of firms varies considerably, as evidenced by the high standard deviation. Further, 73.50 percent of acquiring firms and target firms fall under the same local authority administration; and 60.50 percent of M\&A deals are attributable to related party transactions between target firms and the acquiring firms who control them.

With regards to deal-specific characteristics, the average value of transactions is US\$42.95 million, with a high standard deviation, indicating that target firms vary considerably in size. Among the acquired firms, 94.50 percent of them are private firms, while 5.50 percent are public targets, which is consistent with prior evidence on China (Chi et al., 2011). The popularity of private targets may be because their lower capitalisation and relative weakness make them vulnerable to political bullying by state-controlled firms. Over 90 percent of M\&A transactions are paid by cash; stock-financed M\&A deals constitute $4.60 \%$ which implies that other payment methods account for 4.60 percent. This is consistent with previous studies in which Chi et al. (2011) record 87.00 percent cash transactions, and Tao and Fie (2010) record 80.00 percent cash transactions. Further, 90.20 percent of acquiring firms engage in diversification deals, suggesting a possibility that acquirers attempt to achieve risk diversion through engaging in M\&A deals across different industries. In addition, 73.40 percent of acquiring firms have successfully completed more than one M\&A deal during the sample period, suggesting that the acquirers in China are, in general, experienced.

Concerning product market competition measures, 32.20 percent of acquiring firms operate the competitive industry category, and 26.40 percent of them operate in the unique industry category. These statistics indicate that more acquirers in competitive industries than in unique industries are actively engaged in M\&A activities in China, which may account for managerial behaviour and their decision-making in M\&As.

\section{Empirical Results and Discussions}

Table 5.4 presents the regression results derived from the relationship between the corporate governance mechanism and firm growth, controlling for acquirer characteristics, deal characteristics and product market competition measures. Model 1 focuses on the main variables, ownership and board structure variables. Model 2 introduces acquirers' characteristics variables. Model 3 incorporates deal characteristics variables. 
Model 4 includes the product market competition variables. Model 5 incorporates a single dichotomous variable, the corporate governance index, into the estimation.

The results demonstrate that ownership structure is a distinctive element in the generation of corporate growth. State shares record significant, negative coefficients across all five regression models. These results are significant as they are clear evidence indicating that state ownership hampers corporate growth of the resulting company. Managers in statecontrolled acquiring firms may engage in M\&As to implement the government policy of maximising social welfare. Managers are encouraged to conform to state policy at the expense of economic success, as this confers considerable personal benefits.

More significantly, executive ownership has a highly significant, positive impact on corporate growth. This shows that when the executives own shares, they have an incentive to make rational M\&A decisions to enhance corporate growth. The finding lends support to the agency hypothesis that managerial ownership helps to align managers' and shareholders' interests (Jensen \& Meckling, 1976).

We, however, find little evidence that institutional ownership influences corporate growth, which runs counter to our hypothesis and the findings of Chi et al. (2011). Although it is commonly observed that institutional ownership favours value maximisation, in China it has much less influence upon firm growth. This suggests the possibility that the state which through its agencies, owns about one-third of all institutional shares, compromises the power of institutional investors (Liu et al., $2014 \mathrm{Liu}, 2013$ ).

We find mixed evidence in relation to corporate governance measures. The positive relationship identified between the size of a board and corporate growth indicates that a large board, where members have diversified expertise and experience, can make a positive, collective contribution to M\&A decisions. A smaller board can be easily dominated by a chairman or $\mathrm{CEO}$, who can abuse their power to engage in activities that impair value. This is more likely to occur in Chinese corporate practice, where the right of control is typically concentrated in the hands of a few board members. However, there is little evidence that $\mathrm{CEO}$ /Chairman duality significantly affects corporate growth, though negatively signed. Conspicuously, directors' independence has no impact upon corporate growth $(\mathrm{p}>0.05)$. This is clear evidence to suggest that including independent directors on corporate boards does not contribute towards value-creating M\&A decisions.

Given the insignificance of boards of directors in corporate growth, we consider next if, and how, an integrated corporate governance mechanism may influence firm growth, constructing a corporate governance index in line with DeFond et al. (2005). Our summary measure is constructed from an equally weighted aggregation of the six fundamental governance characteristics comprised of three ownership variables and three board of director variables, to characterise firms as having strong or weak corporate governance. The median value for the summed values 


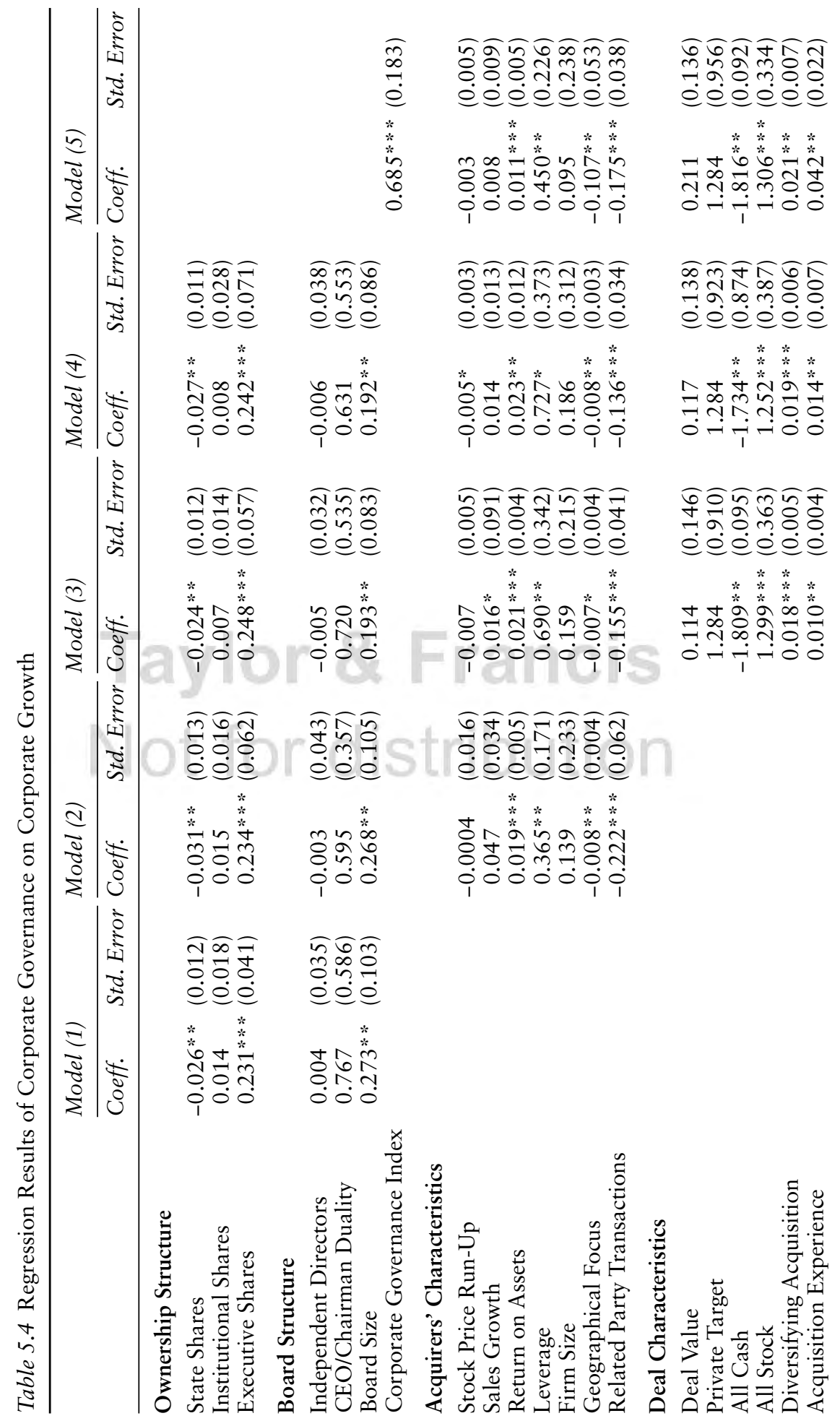




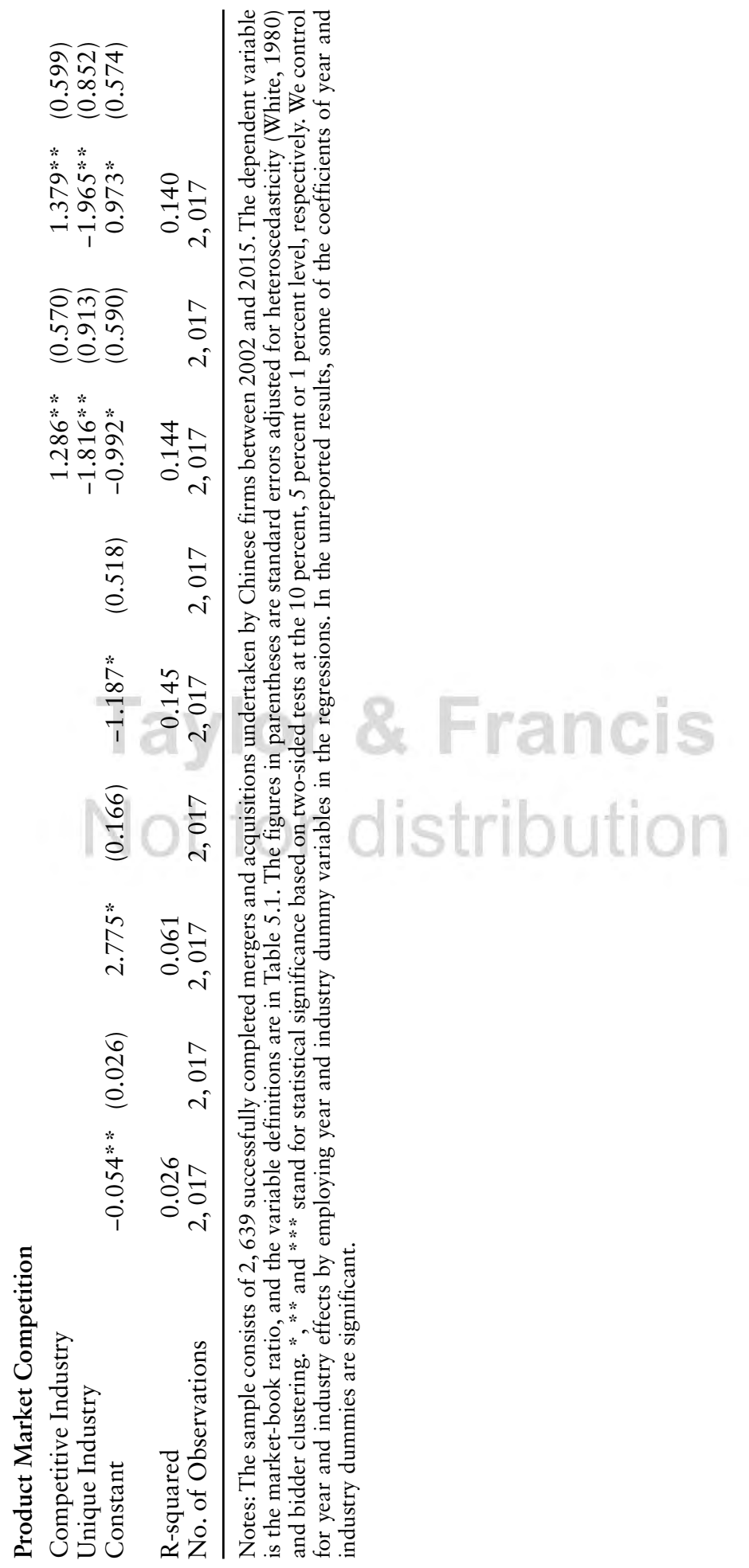




\section{Jia Liu et al.}

is 4.10. Hence, acquiring firms with values of 4.10 and above are classified as having strong corporate governance, while those with values below 4.10 are classified as having weak corporate governance. The results show that 64.26 percent of sample firms have strong corporate governance while 35.74 percent have weak corporate governance. The regression results are presented in Model 5.

It appears that a good, integrated corporate governance mechanism generates a significant, positive effect on the MB-ratio $(\beta=0.685, \mathrm{p}<0.05)$. This clearly demonstrates that an integral corporate governance mechanism plays an important role in aligning congruence of interests between management and shareholders when a company makes an M\&A decision. Such an integrated mechanism can effectively reduce counter-productive agency problems by self-interested parties, enabling truly independent boards on which CEOs, chairmen, independent directors and other directors can fulfil their responsibilities and so enhance the value and sustainability of the combined companies.

Concerning acquirers' characteristics, return on assets has a significant, positive effect, indicating that the greater returns generated from corporate assets will facilitate corporate growth of combined companies. Leverage has a significant, positive impact, providing evidence supporting the agency hypothesis that debt aligns managerial interests with shareholders' thus enhancing corporate growth. Further, M\&A deals that involve acquirers and targets operating in the same administrative provinces has a negative effect, suggesting that geographically diversifying M\&A deals helps to optimise resource reallocation, and at the same time reduce costs, which is in line with the operational synergy hypothesis. The positive effect may also be attributable to favourable support that the companies may possibly gain for cross-provincial M\&A deals from central or local governments, as suggested by Chi et al. (2011). As expected, related party transactions between target firms and the acquiring firms that control them generate a highly significant and negative impact, providing clear evidence to support the argument that the transfer of assets or liabilities between them is perceived by investors to be a stratagem adopted by dominant shareholders for tunnelling resources and disenfranchising minority shareholders. Cheung et al. (2010) have provided evidence that supports the findings of our study. Other variables embodying acquirers' characteristics, such as stock price run-up, sale growth and firm size, have no significant effect on corporate growth.

With regards to deal characteristics, the two different methods of payment generate opposite effects on corporate growth. Deals paid for by stock have a positive effect, consistent with the findings of Faccio et al. (2006); whereas, deals paid for in cash have a negative effect. This suggests that the market does not perceive cash payments to be a means of investing idle cash holdings in a value-enhancing merger; rather, it is seen as management squandering money by investing in M\&A projects that fail to maximise wealth. Further, there is consistent 
evidence that diversifying acquisitions generate positive effects, which suggests that the synergistic gains are realised through economies of scope and scale, greater market and pricing power, elimination of duplicates, and/or reduced agency costs as in Lins and Servaes (2002) or/and more efficient use of human capital as in Trautwein (1990). Further, the positive effect of repeat acquirers indicates that directors with prior acquisition experience help in making value-creating acquisitions. This lends support to the strategic momentum hypothesis that firms tend to follow established strategies that have worked successfully in the past (Pangarkar, 2000). All the other deal characteristics variables are statistically insignificant.

Further, we look at how product market competition influences business growth of firms that are engaged in M\&A activities. We introduce two proxies for product market competition: competitive industry and unique industry (See Table 5.1 for definitions), as in Masulis et al. (2007). The results show that competitive industry has a positive effect on the $\mathrm{MB}$ ratio, while unique industry has a negative effect. They indicate that acquiring firms in competitive product markets make better decisions, supporting the findings of Masulis et al. (2007); whereas, takeovers by acquirers operating in the unique industry category are suggestive of a lack of competition within that sector. Such managers may seek to increase monopoly power alone, enabling them to control prices in a particular market rather than making synergetic gains that impair firm value.

\section{Conclusions and Policy Implications}

In this chapter, we have discussed the internal and external corporate governance mechanisms that China has developed over the past 30 years. Our investigation provides evidence to demonstrate how these systems influence value creation and business growth, emerging from the results of our empirical study into mergers and acquisitions undertaken by Chinese firms between 2002 and 2015. Our empirical investigation has incorporated a wide range of determining factors, representing corporate governance, acquirers' characteristics, deal characteristics and product market competition, and provide significant insights into the problems and prospects of corporate governance in China today.

Our analyses of these factors demonstrate that an integral system of corporate governance, which is respected by boards of directors and constrains and informs their decision-making, will exert a positive effect on corporate growth. However, when we consider the role of independent directors alone, we find that their independence has not exerted a significant influence on corporate growth. These findings are new evidence to support our argument that corporate value creation relies less upon the independence of directors than on an effective, fully integrated system of corporate governance. Indeed, we have observed that 'board independence' in China is not always what it seems. The perceived inefficiencies 


\section{Jia Liu et al.}

of state ownership that pursues social objectives is unlikely to be mitigated by boards whose members have no stake in the companies they run or a lack of independence to run them and, as we have found, merely nod through managerial decisions. This undoubtedly has a negative effect on corporate growth, which is a clear indication that the market associates state-dominated ownership with managerial inefficiencies. On the other hand, corporate executives with shareholdings in an acquiring firm have a positive influence on firm growth, suggesting an alignment of interests between agents and principals. Overall, our study highlights the need for the state to accelerate the reform of the ownership structure, and, in particular, to develop policies that encourage executive ownership, thus helping to align the interests of management and shareholders. Ultimately, it is imperative to install and maintain an effective corporate governance mechanism, in which board independence is real and not merely decorative, and whose decision-making is guided and constrained by the principles of corporate governance.

We believe that our findings are practically relevant because they will direct the attention of managers, investors and the state towards those factors that best enhance corporate value and business growth. Such mature commercial awareness is particularly relevant now that China is faced with global financial instability and slowing growth in the aftermath of the financial crisis. We would argue that our work also has implications for public policy, which should concentrate on building sound internal corporate governance mechanisms and a strong, external regulatory environment. Our findings have implications for other emerging markets too, where weak corporate governance has had a negative effect on much needed inward investment. For example, Okpara and Wynn (2011) note that investment in Nigeria is constrained by weak corporate governance in respect of 'protection of shareholders' rights, lack of commitment of boards of directors, regulatory framework, enforcement and monitoring, ownership concentration, and transparency and disclosure.' Khanna and Zyla (2010) also observe that improved governance systems in Indian companies increased their market valuations and that studies in Russia and Korea have established a causal relationship between the creation of governance mechanisms and firms' improved performance and increased valuations.

The evidence of our study, which consistently shows the importance of an effective corporate governance mechanism in enhancing corporate value and business growth, has shed light on how strong systems of internal corporate governance control, reinforced by external regulation, can work to limit the incentives of managers to engage in value-destroying acquisitions. A corporate governance structure that is strongly influenced by government carries the risk of constraining or of even undermining economic decisions taken for the benefit of commercial activity. Our results demonstrate that a limitation of government intervention can enhance the influence of corporate governance on corporate growth. 
However, this effect cannot be achieved without the presence of efficient and transparent legal and governance systems. The findings of this study further contribute towards an understanding of the importance of internal and external institutional governance creation, so as to enhance investment efficiency and long-term corporate growth.

Our research on China is timely and practically relevant, given the current global economic situation, because our evidence will help to inform the state, managers and investors on how best to improve corporate governance mechanisms so that managers' and shareholders' interests are aligned. The evidence invites government and commerce to ponder the nature, function and independence of boards of directors, and how managers can be empowered to stimulate corporate growth. It is clear that emerging economies in particular will benefit from creating an environment that favours the development of internal systems of governance supported by external regulation. This will reduce the adverse effects of agency problems and tunnelling and facilitate investment efficiency and business growth as a whole.

We should also ponder the significance of these issues for the global community. In the Western world, during the last two or three decades, society has slowly, but surely developed a global conscience. One force driving this movement has been a growing understanding of climate change and its consequences for future generations. First Europe, then the US, and latterly China have sought to limit the production of greenhouse gases, albeit with differing degrees of success. That apart, the growing willingness of nations to adopt policies increasingly benign to the world as a whole, even though detrimental to their individual economies in the short-term, represents, fundamentally, the acceptance that, to use a phrase beloved of David Cameron, 'We are all in this together.'

Once we accept our responsibility to one another on a global scale, we must also accept the need to change systems of governance to the benefit of us all. The so-called 'credit crunch,' that had its origin in the US, drove Europe and the rest of the world into a decade of austerity from which we are now only just beginning to emerge. This begs the question, why did not the systems of governance then in place detect and prevent the creation of the 'junk bonds' that undermined our wealth? Where were the 'big four'or is it the 'big three,' or maybe even the 'big two' audit firms now?-that 'bestride the narrow [accounting] world like a colossus'? Why, if they are so powerful and efficient, did they not prevent yet another massive financial crisis? Had these giants of the accounting world forgotten the examples of Polly Peck and Enron, to list but two in a long gestation of disasters?

Whatever the cause, this represents a chronic failure of governance in the western world and acts as a dire warning to future generations and ourselves that we teeter on the brink of financial Armageddon almost on a daily basis. Why?-because our systems of governance and control have failed us yet again and will continue to do so until they are perfected. 


\section{Jia Liu et al.}

Even in societies with long traditions of accounting probity, this objective is proving difficult enough to achieve. Imagine, therefore, how much more difficult it will be now that China, with its exponentially growing economy and fundamentally flawed systems of governance, increasingly moves centre stage? Will the next global financial disaster originate in Beijing? Is it possible even to foresee what form this might take?

As for the possible trajectory of future research, our argument so far has led us to the conclusion that China's systems of corporate governance are primitive and at an early stage of development. In the country's pell-mell pursuit of economic strength, a sense of global social responsibility seems lacking. Similar comments might be applied to other emerging economies, which undoubtedly suffer from comparable deficiencies. Future research might therefore consider issues of social responsibility and ethical behaviour in takeovers; the levels of commitment to, and enforcement of, corporate governance; firm specific features, such as product quality, employee diversity and the quality of industrial relations and M\&A related-issues, including the benefits of synergy and investor protection mechanisms. Our findings, and those of future research programmes, will have significant policy implications for the state, investors and a rising generation of business managers in the world's emerging economies.

\section{References}

Berkovitch, E., \& Narayanan, M. P. (1993). Motives for Take-overs: An Empirical Investigation. Journal of Financial and Quantitative Analysis, 28, 347-362.

Bunkanwanicha, P., \& Wiwattanakantang, Y. (2009). Big Business Owners in Politics. Review of Financial Studies, 22(6), 2133-2168.

Campbell, R. D., Ghosh, C., Petrova, M., \& Sirmans, C. F. (2011). Corporate Governance and Performance in the Market for Corporate Control: The Case of REITs. Journal of Real Estate Financial Economics, 42, 451-480.

Chen, G., Firth, M., \& Xu, L. (2009). Does the Type of Ownership Control Matter? Evidence from China's Listed Companies. Journal of Banking \& Finance, 33, 171-181.

Cheung, Y. L., Rau, P. R., \& Stouraitis, A. (2010). Helping hand or grabbing hand? Central vs local government shareholders in Chinese listed firms. Review of Finance, 14, 669-694.

Chi, J., Sun, Q., \& Young, M. (2011). Performance and characteristics of bidding firms in the Chinese stock markets. Emerging Markets Review, 12(2), 152-170.

DeFond, M., Hann, R., \& Hu, X. (2005). Does the Market Value Financial Expertise on Audit Committees of Boards of Directors. Journal of Accounting Research, 43(2), 153-193.

Ding, S., Wu, Z., Li, Y., \& Jia, C. (2009). Can the Chinese Two-Tier-Board System Control the Board Chair Pay? Asian Journal of Finance \& Accounting, 1, 1-22.

Doe, J., \& Chan, W. W. Y. (2001). Towards Better Corporate Governance: China's Continuing Struggle. International Financial Law Review, (Fall, 2004), 21-28.

Faccio, M. (2006). Politically Connected Firms. American Economic Review, 96, 369-386. 
Faccio, M., McConnell, J., \& Stolin, D. (2006). Returns to Bidders of Listed and Unlisted Targets. Journal of Financial \& Quantitative Analysis, 41, 197-220.

Fan, J., Wong, T. J., \& Zhang, T. (2007). Politically Connected CEOs Corporate Governance, and Post-IPO Performance of China's Newly Partially Privatized Firms. Journal of Financial Economics, 84, 265-590.

Firth, M. A., Rui, O. M., \& Wu, W. (2011). Cooking the Books: Recipes and Costs of Falsified Financial Statements in China. Journal of Corporate Finance, 17(2), 371-390.

Gaughan, P. A. (2010). Mergers, Acquisitions and Corporate Restructurings. Hoboken, NJ: John Wiley \& Sons.

Jensen, M. C., \& Meckling, W. H. (1976). Theory of the Firm: Managerial Behavior, Agency Costs and Ownership Structure. Journal of Financial Economics, 3, 305-360.

Kakabadse, N. K., Yang, H., \& Sanders, R. (2010). The Effectiveness of NonExecutive Directors in Chinese State-Owned Enterprises. Management Decision, 48, 1063-1079.

Ke, B., Clive, S. L., \& Xin, Q. (2015). The Effect of China's Weak Institutional Environment on the Quality of Big 4 Audits. The Accounting Review, 90(4), 1591-1619.

Khanna, V., \& Zyla, R. (2010). Corporate Governance Matters to Investors in Emerging Market Companies. International Finance Corporation, World Bank Group. Retrieved from https://www.ifc.org/wps/wcm/connect/dbfd8b004afe7d 69bcb6bdb94e6f4d75/IFC_EMI_Survey_web.pdf?MOD=AJPERES

Khwaja, A., \& Mian, A. (2005). Do Lenders Favour Politically Connected Firms? Rent Provision in an Emerging Financial Market. Quarterly Journal of Economics, 120, 1371-1411.

La Porta, R., Lopez-de-Silanes, F., \& Shleifer, A. (1999). Corporate Ownership Around the World. The Journal of Finance, 54(2), 471-518.

La Porta, R., Lopez-de-Silanes, F., Shleifer, A., \& Vishny, R. W. (2000). Investor Protection and Corporate Governance. Journal of Financial Economics, 58, 3-27.

Li, S., Feng, G., \& Cao, G. (2011). Private Benefits of Managerial Control, Government Ownership, and Bidder Returns: Evidence from the Chinese StateControlled Listed Companies. Canadian Journal of Administrative Sciences. doi: $10.1002 /$ cjas. 222

Liang, N., \& Useem, M. (2009). Corporate Governance in China. In Institute of Directors (Ed.), Handbook of international corporate governance (pp. 167-175). London: Institute of Directors, United Kingdom.

Lin, C., Ma, Y., \& Su, D. (2009). Corporate Governance and Firm Efficiency: Evidence from China's Publicly Listed Firms. Managerial \& Decision Economics, 30(3), 93-209.

Lins, K. V., \& Servaes, H. (2002). Is Corporate Diversification Beneficial in Emerging Markets? Financial Management, 31, 5-31.

Liu, G. S., \& Sun, P. (2005). The class of shareholdings and its impacts on corporate performance: a case of state shareholding composition in Chinese public corporations. Corporate Governance: An International Review, 13, 46-59.

Liu, J. (2009). Financial factors and company investment decisions in transitional China. Managerial and Decisions Economics. 30(2), 91-108.

Liu, J. (2013). Fixed investment, liquidity, and access to capital markets: New evidence. International Review of Financial Analysis. 29, 189-201. 


\section{Jia Liu et al.}

Liu, J. and Li. D. R. (2014). The life cycle of initial public offering companies in China. Journal of Applied Accounting Research. 15(3), 291-307.

Liu, J., Akbar, S., Shah, S. Z. A., Zhang, D., \& Pang, D. (2016). Market Reaction to Seasoned Offerings in China. Journal of Business Finance \& Accounting, 43(5-6), 597-653.

Liu, J., Lister, R., and Pang, D. (2012). Corporate evolution following initial public offerings in China: A life-course approach. International Review of Financial Analysis. 27, 1-134.

Liu, J; Wu, Y, Ye, Q and Zhang, D (2018). Does Seasoned Equity Finance promote Survival of Firms International Review of Financial Analysis. https://doi. org/10.1016/j.irfa.2018.08.001

M. Gao, H. Qian and Liu. J. (2018). Managerial overconfidence and M\&A performance: Evidence from China. International Journal of Banking, Accounting and Finance. Forthcoming.

Masulis, R. W., Wang, C., \& Xie, F. E. I. (2007). Corporate Governance and Bidder Returns. The Journal of Finance, 62, 1851-1889.

Okpara, J. O., \& Wynn, P. (2011). Corporate Governance in Emerging Markets: Barriers to Effective Reform. Society for Advancement of Management: Advanced Management Journal: Corpus Christi, 76(1), 24-32.

Pangarkar, N. (2000). What drives merger behaviour of firms? Strategic Momentum vs Bandwagons. International Journal of Organizational Theory \& Behavior, 3(1 and 2), 37-72.

Petitt, B. S., \& Ferris, K. R. (2013). Valuation of Mergers and Acquisitions (2nd ed.). New Jersey: TF Press.

Pukthuanthong-Le, P., \& Visaltanachoti, N. (2009, October 21-24). Who benefits from M\&A? Evidence from China. Paper presented at the FMA Annual Conference, Reno, Nevada.

Roll, R. (1986). The Hubris Hypothesis of Corporate Takeovers. Journal of Business, 59, 197-216.

Tao, L., \& Fie, X. (2010, July 9-11). The payment pattern of merger and acquisition: An empirical analysis from China's listed companies. Paper presented at the Advanced Management Science (ICAMS), IEEE International Conference, Chengdu, China.

Trautwein, F. (1990). Merger Motives and Merger Prescriptions. Strategic Management Journal, 11(4), 283-295.

Wang, Y., \& Hickson, C. (2009). Shareholder wealth effects of MঊA: Evidence from the UK. Working Study Series, No. MS_WPS_FIN_09_8, Queen's University Management School, Belfast: UK.

Wei, D., \& Geng, M. (2008). Ownership Structure and Corporate Governance in China: Some Current Issues. Managerial Finance, 34, 934-952.

Weitzel, U., \& McCarthy, K. L. (2011). Theory and Evidence on M\&A by Small and Medium Enterprises. International Journal of Entrepreneurship \& Innovation Management, 14, 248-275.

White, H. (1980). A Heteroskedasticity-Consistent Covariance Matrix Estimator and a Direct Test for Heteroskedasticity. Econometrica, 48, 817-838.

World Bank (2017). The World Bank in China. www.worldbank.org./en/country/ china/overview.

Zhang, X. (2003). Do M\&A create value: Evidence from Chinese listed companies. Economic Research Journal, 6, 20-30. 